\title{
Suicide in Hungary-epidemiological and clinical perspectives
}

\author{
Zoltan Rihmer ${ }^{1,2}$, Xenia Gonda ${ }^{1 *}$, Balazs Kapitany ${ }^{3}$ and Peter Dome ${ }^{1}$
}

\begin{abstract}
Annual suicide rates of Hungary were unexpectedly high in the previous century. In our narrative review, we try to depict, with presentation of the raw data, the main descriptive epidemiological features of the Hungarian suicide scene of the past decades. Accordingly, we present the annual suicide rates of the period mentioned and also data on how they varied by gender, age, urban vs. rural living, seasons, marital status, etc. Furthermore, the overview of trends of other factors that may have influenced suicidal behavior (e.g., alcohol and tobacco consumption, antidepressant prescription, unemployment rate) in the past decades is appended as well. Based on raw data and also on results of the relevant papers of Hungarian suicidology we tried to explain the observable trends of the Hungarian suicide rate. Eventually, we discuss the results, the possibilities, and the future tasks of suicide prevention in Hungary.
\end{abstract}

Keywords: Hungary, Suicide, Suicidal behavior, Epidemiology, Risk factors, Prevention

\section{Introduction}

Suicidal behavior is a major public health problem worldwide, and its prediction and prevention receives increasing attention. Approximately 1 million people die by suicide in the world every year, and it is estimated that 1.5 million will die from suicide in 2020 . The global suicide rate of the world is 14 suicides per 100,000 inhabitants: more specifically, 18 suicides per 100,000 males and 11 suicides per 100,000 females [1,2]. In spite of the fact that suicide rates of different countries and continents differ substantially, the rate of completed suicide, in general, is much higher among males, among older people, and among Caucasians.

Although suicide is a very complex, multi-causal behavior, involving several medical-biologic and psycho-social components, history of untreated major psychiatric (particularly depressive and alcohol-related) disorders constitute the most important risk factors. However, lifetime and current psycho-social and personality factors (stressful life events, financial problems, unemployment, impulsivity) and other forms of addictive behaviors than drinking (e.g., cigarette smoking) have been also found to be in a statistically significant positive relationship with suicide mortality [3-8].

\footnotetext{
* Correspondence: kendermagos@yahoo.com

${ }^{1}$ Department of Clinical and Theoretical Mental Health, Faculty of Medicine, Semmelweis University, Budapest, Hungary

Full list of author information is available at the end of the article
}

The highest annual suicide rates are reported from Eastern Europe (13-42 suicides per 100,000 persons) followed by Western/Nordic European countries (8-21 suicides per 100,000 persons) and North America and Australia (11-13 suicides per 100,000 persons). Latin America, as well as 'Latin Europe' (Greece, Spain, Italy), and Central Asian countries report annual suicide rates less than $10[1,9,10]$. Reasons for these great differences between national/regional suicide rates have not been fully explained. Geographic, climatic, socio-cultural, dietary, religious, and economic differences can be taken into account, but differences in the psychiatric morbidity as well as the accuracy of the registration of suicide, the stigma associated with suicide possibly influencing reporting rates, the availability of lethal methods, and the availability of the social/health care system should also be considered [4,11].

The primary aim of our narrative review, based on both raw data retrieved from the databases of the Hungarian Central Statistical Office and papers published in international journals (identified by Pubmed searches using keyword combinations 'suicide + Hungary', 'suicidal + Hungary'; 'suicide + Hungarian'; 'suicidal + Hungarian') and also on papers/books in Hungarian (identified by Google), is to present the main characteristic features of the Hungarian suicide scene of the last 50 years and also to append some possible explanations of the trends observed. 


\section{Review}

\section{Suicide in Hungary-an introduction}

Suicide rates are high in large parts of Northern and Eastern Europe, and some of the highest figures have been reported in Hungary $[1,10]$. In addition to psycho-social factors, several lines of evidence indicate genetic and biological contributions to unexpectedly high Hungarian suicide rate [12]. Within Europe, the countries with the highest suicide rate constitute a contiguous J-shaped belt from Finland through the Baltic countries, Russia, Belarus, and Ukraine to central Europe (Hungary, Slovenia, Austria) [12]. Genetic similarities observed between populations of these countries led to the Finno-Ugrian suicide hypothesis which states that high suicide rates of these countries are the consequence of a shared genetic susceptibility [12]. Genetic background of this phenomenon is very probable because other (e.g., cultural/socio-political/economic) features of these countries are quite different. Consonant with the theory about the genetic background of the high suicide rate of Hungary, Hungarian immigrants in the USA have the highest suicide rates of all immigrant groups [11]. In addition, the existence of an unfortunate genetic/cultural susceptibility of Hungarians to suicidal behavior is further bolstered by the fact that suicide rates of those Romanian counties where the proportions of Hungarian people are high (e.g., Harghita, Covasna, Mures) were much higher than of those counties where the population percentages of Hungarians are low [13].

Between 1960 and 2000 in the vast majority of years, the suicide rate of Hungary was the highest in the world. The reason of this very high suicide mortality of Hungary is not fully understood. It is one possibility is that the medical examiners in Hungary certify those deaths as suicide which would otherwise be labeled as undetermined death or as death related to other causes. However, the highest suicide rate of Hungarian immigrants in the USA [11] and the similarly high suicide rate of ethnic Hungarians living in Romania [13] contradict this possibility. Political or economic causes are also very unlikely, as between 1960 and 1990 the suicide rates of Poland, Bulgaria, Romania, and former Yugoslavia (countries with similar political and economic systems) were around one third of the Hungarian figure, and during the mentioned period, in the majority of the years, the suicide mortality of Denmark, Finland, Austria, and Sweden (with much more advantageous political and economic situations) have been among the top ten in the world. As mentioned above, the most established risk factor(s) of suicide are different forms of (untreated) major affective disorders. Although direct comparison of national epidemiological data on prevalences of affective disorders is not fortunate due to some methodological issues (e.g., different studies have frequently used different diagnostic instruments), it can be said that lifetime prevalence of 'any' bipolar disorder, which carries the highest risk of suicide [14-16], is unusually high in Hungary (5.1\%) [17,18]. Albeit, lifetime prevalence of major depressive disorder according to the DSM-IV criteria in the Hungarian population (15.1\%) is similar to the corresponding data from other European countries and the USA, a recent study, assessing depressive symptoms using CES-D in the general population of 23 European countries, reported the highest mean scores in Hungary among all investigated countries [19,20]. In summary, these results raise the possibility that high prevalence of affective (especially bipolar) disorders (and possibly also subthreshold manifestations of bipolarity and bipolar spectrum disorders) in the Hungarian population may be one of the most important contributors to the markedly high suicide rate of Hungary.

Looking at European countries with the highest suicide rates 25 years ago (between 20 and 46 per 100,000 per year), the $26 \%-54 \%$ decline in the national suicide rates of Hungary, Denmark, Germany, Austria, Estonia, Switzerland, Sweden, and Finland in the last 2 decades is quite impressive [3,10,21-23]. However, given the recent economic crisis, suicide rates are stabilized or show a slight increase in many European countries [24,25].

\section{Suicide mortality of Hungary between 1961 and 2010 Time trends, gender distribution, and method of suicide}

Figure 1 and Table 1 show the suicide rate of Hungary between 1961 and 2011. There was a steady increase in suicide mortality between 1961 (25.5/100,000/year) and 1983. The peak of suicide rate was in 1983 (45.9/100,000/ year). After 1983, the suicide rate remained virtually unchanged ( $\approx 44-45 / 100,000 /$ year) until the year 1988 when a sharp and longstanding decline began (this steady decline lasted until 2007 (24.3/100,000/year), and the suicide rate stabilized at this level up to now). By virtue of the striking coincidence of the beginning of decline in (total) suicide rate and the political transition in Hungary (1988-1989) some authors raised the possibility that the termination of the communist regime was reflected in the decrease of suicide rate. At the same time, however, the increasing trend of female suicide rate turned into a decline already in the beginning of the 1980s so the beneficial effect of political transition on suicide rate, at least in the case of females, is questionable [26].

In Hungary, similar to the great majority of developed countries, males consistently show much higher suicide rates than females [2,27]. However, the female suicide rate decreased more markedly between 1983 and 2010 (females, 61\% decline; males, 39\% decline) and while the male-to-female suicide ratio was 2.53 in 1983, the same figure was 3.93 in 2010.

Table 2 displays the distribution of violent and nonviolent suicide cases by gender in the years 1980, 1995, and 2010. 


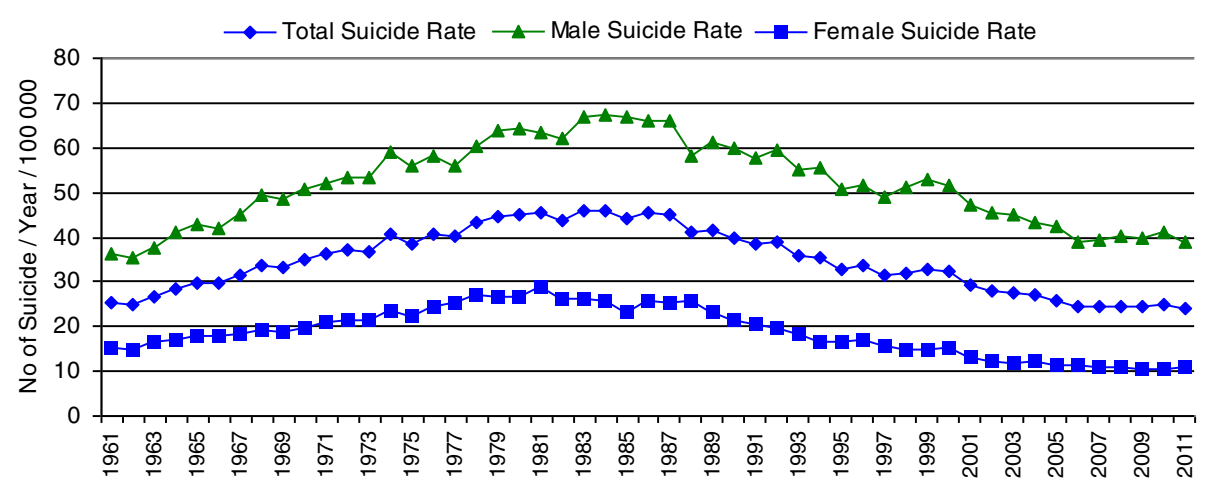

Figure 1 Total, male, and female suicide rates (per 100,000/year) in Hungary from 1961 to 2011.

In accordance with world trends, the proportion of violent suicides among all suicides is higher in males than in females in Hungary [27,28]. Although during this 30-year period, the total suicide mortality of Hungary has decreased substantially, the proportion of violent suicide cases has increased markedly and strictly both in males and females (Table 2). This can reflect the fact that improved care of psychiatric patients (including less toxic psychotropics and higher level of intensive care) can save more lives in the case of nonviolent attempts (overdose, poisoning), while violent suicide methods (hanging, shooting, drowning, etc.) are more rapid and mostly irreversible [29].

In line with data from the majority of other countries, suicide attempts are more prevalent among females than among males in Hungary as it was suggested by results of studies conducted in consecutive series of suicide attempters in different areas of the country (Budapest, Pécs, Győr) and also in a sample representative of the Hungarian population $(\mathrm{n}=2.953$; number of suicide attempters =94) $[15,30-32]$. According to the unpublished data of the Hungarian National Ambulance Emergency Service, the number of 'suicide events' (which mainly mirrors suicide attempts) decreased in a monotonic and relevant manner from 1986 to 2006 (from 23,729 to 8,025). After 2007 (till 2011), the values were between 8,256 and 8,795 (Göbl and Andics, personal communication). Accordingly, trends in suicide attempts roughly followed the trends in completed suicide (a decrease from the mid 1980s to 2006 and a stabilization period from 2007 till now). Previously, we have already provided some supposed explanations (and later we will provide others) for the decreasing part of the curve of suicide rate (observable from the mid 1980s to 2006). However, there are no exact explications to the disappearance of the declining trend from the suicide rate from 2007 till now, it is probable that increasing unemployment and restrictions/ destructions with which Hungarian psychiatry had to be faced in the last few years may contribute to this unfavorable turn $[25,33]$.

\section{Alcohol consumption, antidepressant prescription, unemployment, and cigarette smoking}

Table 3 shows the data on alcohol consumption, antidepressant prescription, unemployment, and tobacco consumption in Hungary between 1961 and 2011. All of them have been reported in the literature to be in a statistically significant relationship with suicide mortality; unemployment, alcohol, and tobacco consumption shows a positive, and antidepressant prescriptions a negative correlation [3,5-8,23,34,35]. However, during the time period from 1985 to 2008 , only antidepressant prescription and tobacco consumption showed significant associations (a negative and a positive, respectively) with suicide mortality in Hungary while alcohol consumption and changes in GDP did not [8].

\section{Age distribution, marital status}

Table 4 shows the age distribution of suicide cases in the total, male, and female populations. In Hungary, similarly to the majority of European countries, total, male, and female suicide rates mainly increase with age (there are also some exceptions, e.g., Ireland (in both genders) and Finland (in females), whose suicide rate reaches its maximum in middle-aged cohorts and declines in elderly) $[2,36]$. A plateau (or a slight decrease) of the suicide rate after midlife (in cohorts aged $\approx 60-70$ years old) was also observable in the case of the Hungarian total population in the year 2010. This bimodal pattern (with a smaller maximum of the curve in the cohorts aged 30-50 (60) years and a bigger maximum of the curve after age 75 ) is slightly reminiscent of findings from some other European countries (e.g., Austria, Belgium, Czech Republic, Estonia, Latvia) [2].

Table 5 shows suicide rates in groups with different marital statuses. As it can be seen, the highest suicides rates are associated with divorced and widowed statuses while the lowest rates can be observed among those who are married. Investigating the regional distribution of divorce rates and suicide rates in 20 regions of Hungary 
Table 1 Suicide rates ( $n / 100,000 / y e a r)$ for Hungarian total, male, and female populations between 1961 and 2011

\begin{tabular}{|c|c|c|c|}
\hline Year & Total suicide rate & Male suicide rate & Female suicide rate \\
\hline 1961 & 25.50 & 36.41 & 15.33 \\
\hline 1962 & 24.90 & 35.60 & 14.91 \\
\hline 1963 & 26.80 & 37.53 & 16.78 \\
\hline 1964 & 28.60 & 40.94 & 17.08 \\
\hline 1965 & 29.89 & 42.68 & 17.92 \\
\hline 1966 & 29.63 & 42.10 & 17.98 \\
\hline 1967 & 31.38 & 45.18 & 18.47 \\
\hline 1968 & 33.80 & 49.23 & 19.35 \\
\hline 1969 & 33.20 & 48.41 & 18.94 \\
\hline 1970 & 34.84 & 50.76 & 19.86 \\
\hline 1971 & 36.09 & 52.06 & 21.07 \\
\hline 1972 & 36.99 & 53.49 & 21.46 \\
\hline 1973 & 36.92 & 53.24 & 21.55 \\
\hline 1974 & 40.79 & 59.03 & 23.62 \\
\hline 1975 & 38.56 & 55.95 & 22.17 \\
\hline 1976 & 40.74 & 58.10 & 24.38 \\
\hline 1977 & 40.39 & 56.13 & 25.56 \\
\hline 1978 & 43.20 & 60.51 & 26.89 \\
\hline 1979 & 44.58 & 63.64 & 26.62 \\
\hline 1980 & 44.90 & 64.45 & 26.54 \\
\hline 1981 & 45.55 & 63.47 & 28.73 \\
\hline 1982 & 43.50 & 61.99 & 26.15 \\
\hline 1983 & 45.90 & 66.74 & 26.36 \\
\hline 1984 & 45.89 & 67.51 & 25.64 \\
\hline 1985 & 44.34 & 66.94 & 23.20 \\
\hline 1986 & 45.27 & 66.04 & 25.88 \\
\hline 1987 & 45.02 & 65.87 & 25.57 \\
\hline 1988 & 41.28 & 58.09 & 25.60 \\
\hline 1989 & 41.52 & 61.33 & 23.06 \\
\hline 1990 & 39.84 & 59.78 & 21.39 \\
\hline 1991 & 38.56 & 57.92 & 20.68 \\
\hline 1992 & 38.70 & 59.25 & 19.73 \\
\hline 1993 & 35.83 & 54.92 & 18.24 \\
\hline 1994 & 35.27 & 55.39 & 16.77 \\
\hline 1995 & 32.88 & 50.53 & 16.68 \\
\hline 1996 & 33.67 & 51.64 & 17.19 \\
\hline 1997 & 31.59 & 49.10 & 15.55 \\
\hline 1998 & 32.04 & 50.99 & 14.70 \\
\hline 1999 & 32.98 & 52.93 & 14.75 \\
\hline 2000 & 32.55 & 51.40 & 15.35 \\
\hline 2001 & 29.21 & 47.04 & 13.03 \\
\hline 2002 & 27.94 & 45.38 & 12.14 \\
\hline 2003 & 27.62 & 44.85 & 12.02 \\
\hline
\end{tabular}

Table 1 Suicide rates $(n / 100,000 / y e a r)$ for Hungarian total, male, and female populations between 1961 and 2011 (Continued)

\begin{tabular}{llll}
\hline 2004 & 27.10 & 43.44 & 12.33 \\
2005 & 25.96 & 42.31 & 11.18 \\
2006 & 24.42 & 38.90 & 11.34 \\
2007 & 24.34 & 39.32 & 10.80 \\
2008 & 24.66 & 40.07 & 10.73 \\
2009 & 24.53 & 39.93 & 10.61 \\
2010 & 24.88 & 40.89 & 10.40 \\
2011 & 24.25 & 38.93 & 10.97 \\
\hline
\end{tabular}

Source: Hungarian Central Statistical Office, Budapest, Hungary.

we have previously reported a significant positive association; higher suicide rate in the given region was associated with higher divorce rate and vice versa [37]. These findings are in accordance with observations from other countries [36,38-40].

\section{Regional distribution, urban-rural differences}

Similarly to some other countries, marked regional differences in suicide rates are present in Hungary [41-43]. As shown in Figure 2a, b the suicide rates are higher in the south-eastern than in the north-western parts of the country. This pattern is quite stable in time (the first mention of this phenomenon was in the year 1864) [42-44]. Although some possible explanations of the spatial inequality of suicide rates have been proposed (e.g., the proportion of Protestants is higher in the south-eastern region; there are also differences in attitudes toward suicide and levels of social integration in the Durkheimian sense between populations with high vs. low suicide rates) the exact explanations are still missing $[26,42,43]$. The only study that tried to explore the cause(s) of the marked regional differences in suicide mortality in Hungary based on exact data found a significant negative correlation between the suicide rates and the rates of treated depressions in 19 counties of Hungary; the higher was the rate of recognized (treated) depression the lower was the suicide rate in the given county [42]. However, this cannot be a full explanation,

Table 2 Distribution (\%) of violent and nonviolent suicides in Hungarian populations in 1980, 1995, and 2010

\begin{tabular}{ccccc}
\hline Population & Method of suicide & $\mathbf{1 9 8 0}$ & $\mathbf{1 9 9 5}$ & $\mathbf{2 0 1 0}$ \\
\hline Male & Violent & $77.4 \%$ & $85.81 \%$ & $89.9 \%$ \\
& Nonviolent & $22.6 \%$ & $14.19 \%$ & $10.1 \%$ \\
\multirow{2}{*}{ Female } & Violent & $51.5 \%$ & $59.02 \%$ & $67.3 \%$ \\
& Nonviolent & $48.5 \%$ & $40.98 \%$ & $32.7 \%$ \\
\hline
\end{tabular}

Source: Hungarian Central Statistical Office, Budapest, Hungary. 
Table 3 Alcohol and tobacco consumption, antidepressant use, unemployment rates and total suicide rates in Hungary

\begin{tabular}{|c|c|c|c|c|c|c|c|}
\hline Year & $\begin{array}{l}\text { Pure (absolute) } \\
\text { alcohol consumption } \\
\text { (in liters per capita) }\end{array}$ & $\begin{array}{l}\text { Antidepressant } \\
\text { use (DDD/1,000 } \\
\text { inhabitants/day) }\end{array}$ & $\begin{array}{l}\text { Unemployment } \\
\text { rate (total) }\end{array}$ & $\begin{array}{l}\text { Unemployment } \\
\text { rate (male) }\end{array}$ & $\begin{array}{l}\text { Unemployment } \\
\text { rate (female) }\end{array}$ & $\begin{array}{l}\text { Tobacco consumption } \\
\text { (in kilogram per capita) }\end{array}$ & $\begin{array}{l}\text { Total suicide rate } \\
\text { (per 100,000/year) }\end{array}$ \\
\hline 1961 & 6.1 & & & & & & 25.50 \\
\hline 1962 & 6.2 & & & & & & 24.90 \\
\hline 1963 & 6.5 & & & & & & 26.80 \\
\hline 1964 & 7.3 & & & & & & 28.60 \\
\hline 1965 & 6.8 & & & & & & 29.89 \\
\hline 1966 & 6.9 & & & & & & 29.63 \\
\hline 1967 & 7.5 & & & & & & 31.38 \\
\hline 1968 & 7.7 & & & & & & 33.80 \\
\hline 1969 & 8.7 & & & & & & 33.20 \\
\hline 1970 & 9.1 & & & & & & 34.84 \\
\hline 1971 & 9.5 & & & & & & 36.09 \\
\hline 1972 & 9.5 & & & & & & 36.99 \\
\hline 1973 & 9.5 & & & & & & 36.92 \\
\hline 1974 & 9.4 & & & & & & 40.79 \\
\hline 1975 & 10.1 & & & & & & 38.56 \\
\hline 1976 & 10.7 & & & & & & 40.74 \\
\hline 1977 & 11.3 & & & & & & 40.39 \\
\hline 1978 & 11.5 & & & & & & 43.20 \\
\hline 1979 & 11.1 & & & & & & 44.58 \\
\hline 1980 & 11.7 & & & & & & 44.90 \\
\hline 1981 & 11.5 & & & & & & 45.55 \\
\hline 1982 & 11.6 & & & & & & 43.50 \\
\hline 1983 & 11.4 & & & & & & 45.90 \\
\hline 1984 & 11.7 & & & & & & 45.89 \\
\hline 1985 & 11.6 & 2.67 & & & & 2.1 & 44.34 \\
\hline 1986 & 11.5 & 2.74 & & & & 2.2 & 45.27 \\
\hline 1987 & 10.8 & 2.80 & & & & 2.1 & 45.02 \\
\hline 1988 & 10.5 & 3.10 & & & & 2.1 & 41.28 \\
\hline 1989 & 11.3 & 3.40 & & & & 2.2 & 41.52 \\
\hline 1990 & 11.1 & 3.70 & & & & 2.0 & 39.84 \\
\hline 1991 & 10.7 & 3.80 & & & & 1.8 & 38.56 \\
\hline 1992 & 10.5 & 3.90 & 9.9 & 11.0 & 8.7 & 1.7 & 38.70 \\
\hline 1993 & 10.6 & 4.03 & 12.1 & 13.5 & 10.4 & 1.6 & 35.83 \\
\hline 1994 & 10.5 & 5.18 & 10.8 & 12.1 & 9.4 & 1.6 & 35.27 \\
\hline 1995 & 10.0 & 6.48 & 10.3 & 11.6 & 8.7 & 1.5 & 32.88 \\
\hline 1996 & 10.3 & 8.13 & 10.0 & 10.9 & 8.8 & 1.4 & 33.67 \\
\hline 1997 & 10.1 & 10.13 & 8.8 & 9.6 & 7.8 & 1.5 & 31.59 \\
\hline 1998 & 10.2 & 12.29 & 7.8 & 8.5 & 7.0 & 1.6 & 32.04 \\
\hline 1999 & 10.1 & 13.28 & 7.0 & 7.5 & 6.3 & 1.7 & 32.98 \\
\hline 2000 & 10.0 & 13.65 & 6.4 & 7.0 & 5.6 & 1.5 & 32.55 \\
\hline 2001 & 11.1 & 16.28 & 5.7 & 6.3 & 5.0 & 1.5 & 29.21 \\
\hline 2002 & 11.2 & 18.28 & 5.8 & 6.1 & 5.4 & 1.5 & 27.94 \\
\hline 2003 & 11.1 & 21.25 & 5.9 & 6.1 & 5.6 & 1.5 & 27.62 \\
\hline
\end{tabular}


Table 3 Alcohol and tobacco consumption, antidepressant use, unemployment rates and total suicide rates in Hungary (Continued)

\begin{tabular}{|c|c|c|c|c|c|c|c|}
\hline 2004 & 11.1 & 20.88 & 6.1 & 6.1 & 6.1 & 1.4 & 27.10 \\
\hline 2005 & 11.0 & 23.57 & 7.2 & 7.0 & 7.5 & 1.4 & 25.96 \\
\hline 2006 & 11.2 & 25.41 & 7.5 & 7.2 & 7.8 & 1.5 & 24.42 \\
\hline 2007 & 10.7 & 24.61 & 7.4 & 7.1 & 7.6 & 1.5 & 24.34 \\
\hline 2008 & 10.0 & 26.24 & 7.8 & 7.6 & 8.1 & 1.6 & 24.66 \\
\hline 2009 & 9.8 & 26.33 & 10.0 & 10.3 & 9.7 & & 24.53 \\
\hline 2010 & & 27.08 & 11.2 & 11.6 & 10.7 & & 24.88 \\
\hline 2011 & & 27.60 & 10.9 & 11.0 & 10.9 & & 24.25 \\
\hline
\end{tabular}

Data taken between 1961 and 2011. Source: Hungarian Central Statistical Office, Budapest, Hungary; $[8,25]$.

because the mentioned regional difference in suicide mortality of Hungary has been present several decades before the introduction of antidepressants. However, looking at the severity of depressive symptoms, as measured by the Beck Depression Inventory, in a representative sample of Hungarian population it was found that the highest mean total Beck scores were found in North-East Hungary, where the suicide rates were also the highest $[45,46]$. Intriguingly, some results suggest that those subjects who were born in Hungarian areas with high-suicide rates have a higher chance of committing suicide after relocating to other regions from their place of birth [43,47]. It is also noteworthy that differences between suicide rates of districts in the capital city Budapest (some of them having a number of inhabitants greater than 100,000) are also remarkable. For example, in the year 1990, the district with the highest suicide mortality had a 49.1/100,000/year suicide rate, while the district with the lowest suicide mortality had a 20.5/100,000/year suicide rate in Budapest.

Table 6 shows the trends in suicide rates of the total, male, and female populations according to an 'urban-rural' approach. Although, as shown in the table, in 1970 there was no remarkable difference between the suicide rates of urban and rural areas in the total population, a growing gap between urban and rural suicide rates is observable on the long run. Accordingly, a clear trend has evolved up to 2010: the greater the level of urbanicity, the lower the level of suicide rate. This phenomenon is in accordance with observations from several other countries [48]. In females, there was an obvious association between domicile and suicide rate in all years examined (1970, 1980, 2010): suicide rates were higher for those females who lived in urban than for those who lived in rural regions (but to the end of the observation period, the difference had almost entirely dissipated). A diametrically opposite trend may be observed among males. Very similar results were reported from the nearby Austria regarding the same period [48].

\section{Seasonal and other temporal components of suicidal behavior}

Several epidemiological studies have suggested that the numerical distribution of suicide cases is uneven during the calendar year [49]. According to highly replicated results, there is a peak in the number of suicide cases in the spring and early summer (in some studies, a smaller peak in the autumn for females), and a trough in the winter. In general, violent suicide cases (typical for males) are mainly responsible for the seasonal inequality

Table 4 Distribution of suicide rates ( $n / 100,000 / y e a r)$ by age in populations in Hungary in 1980 and 2010

\begin{tabular}{|c|c|c|c|c|c|c|}
\hline \multirow{2}{*}{$\begin{array}{l}\text { Age group } \\
\text { (years) }\end{array}$} & \multicolumn{2}{|c|}{ Total population } & \multicolumn{2}{|c|}{ Male population } & \multicolumn{2}{|c|}{ Female population } \\
\hline & SR (1980) & SR (2010) & SR (1980) & SR (2010) & SR (1980) & SR (2010) \\
\hline $10-19$ & 8.2 & 3.4 & 11.90 & 4.58 & 4.27 & 2.22 \\
\hline $20-29$ & 30.3 & 11.8 & 48.42 & 19.16 & 11.57 & 4.09 \\
\hline $30-39$ & 48.6 & 19.1 & 74.88 & 32.04 & 22.13 & 5.59 \\
\hline $40-49$ & 63.0 & 35.1 & 94.79 & 57.28 & 33.34 & 13.23 \\
\hline $50-59$ & 68.1 & 42.5 & 104.53 & 72.39 & 36.21 & 16.11 \\
\hline $60-69$ & 72.1 & 37.8 & 98.64 & 65.18 & 51.20 & 16.95 \\
\hline $70-79$ & 102.0 & 39.9 & 157.20 & 79.22 & 64.62 & 17.25 \\
\hline $80-89$ & 138.6 & 49.7 & 211.81 & 114.53 & 101.84 & 21.83 \\
\hline 90 and above & 192.6 & 70.3 & 337.66 & 146.20 & 134.74 & 41.52 \\
\hline
\end{tabular}

SR, suicide rate. Source: Hungarian Central Statistical Office, Budapest, Hungary. 
Table 5 Hungarian suicide rates $(n / 100,000 /$ year) in groups with different marital status in 1980 and 2010

\begin{tabular}{|c|c|c|c|c|}
\hline Marital status & Gender & Age (years) & 1980 & 2010 \\
\hline \multirow[t]{6}{*}{ Unmarried } & Male & $15-39$ & 50.94 & 20.71 \\
\hline & & $40-59$ & 145.52 & 80.14 \\
\hline & & 60 and above & 131.27 & 145.32 \\
\hline & Female & $15-39$ & 13.97 & 5.38 \\
\hline & & $40-59$ & 58.93 & 17.97 \\
\hline & & 60 and above & 59.62 & 12.14 \\
\hline \multirow[t]{6}{*}{ Married } & Male & $15-39$ & 46.93 & 23.27 \\
\hline & & $40-59$ & 84.7 & 43.31 \\
\hline & & 60 and above & 103.35 & 52.18 \\
\hline & Female & $15-39$ & 12.35 & 2.94 \\
\hline & & 40-59 & 26.56 & 9.72 \\
\hline & & 60 and above & 40.03 & 9.1 \\
\hline \multirow[t]{6}{*}{ Widowed } & Male & $15-39$ & 229.8 & 196.17 \\
\hline & & $40-59$ & 233.8 & 208.96 \\
\hline & & 60 and above & 272.7 & 155.38 \\
\hline & Female & $15-39$ & 65.84 & 0.0 \\
\hline & & $40-59$ & 62.34 & 24.26 \\
\hline & & 60 and above & 78.36 & 23.72 \\
\hline \multirow[t]{6}{*}{ Divorced } & Male & $15-39$ & 189.76 & 63.11 \\
\hline & & $40-59$ & 251.88 & 117.16 \\
\hline & & 60 and above & 172.37 & 123.21 \\
\hline & Female & $15-39$ & 47.75 & 7.44 \\
\hline & & $40-59$ & 68.15 & 24.52 \\
\hline & & 60 and above & 87.84 & 27.25 \\
\hline
\end{tabular}

Source: Hungarian Central Statistical Office, Budapest, Hungary.

of suicide rates [49]. Studies show that this type of seasonality is mainly the consequence of the seasonal incidence of depression-related suicides [50,51]. The majority of longitudinal investigations provided some evidence that seasonality in suicidal behavior has decreased in the latest decades $[23,52,53]$, but some studies from other countries have found either increasing or unchanging trends in suicide seasonality [49]. Some studies suggest that the decreasing seasonality of suicides could be a good marker of the lowering rate of depression-related suicides in the population particularly among males $[23,53,54]$. The Hungarian data are in line with the abovementioned results from other countries. Accordingly, the first Hungarian data set in which the spring peak for suicide was demonstrated was derived from the 1930s (seasonal pattern was similar for both sexes) [55]. Analyses using data from later years (1980-1999 in one study, 1970-2000 in another study, and 1998-2006 in a third study) have also confirmed a peak in the number of suicides in the spring-summer period and a trough in the autumn-winter period [23,56,57]. Only one of these studies investigated genders separately, and this one did not find the abovementioned, autumn peak for females [57]. All three studies reported that seasonal fluctuation of suicide was decreasing during the periods examined $[23,56,57]$. The one study which investigated seasonal fluctuation of suicide by age found that the decrease pertains only to the young cohorts, while Sebestyén et al. described that the decrease in suicide seasonality is mainly the consequence of the significant decrease among males $[23,57]$. Tables 7,8 , and 9 present the seasonal distribution of suicide cases in the last decades in the Hungarian total, male, and female populations.

Another highly confirmed and noteworthy result regarding temporal variations of suicide is that more subjects commit suicide in the first days of the week than in the weekend [58,59]. In Hungary, between 1970 and 2002, the average number of suicides peaked on Monday for both sexes and was lowest on Saturday (for males) and Sunday (for females) [59].

\section{Decreasing suicide mortality in Hungary: what is beyond the figures?}

Although the traditionally high suicide rate of Hungary is the second highest in the European community and the fifth to sixth highest in Europe, characteristics of suicidal behavior (gender, age, and urban-rural distribution, method of suicide, marital status, seasonality, rate of psychiatric morbidity) are very similar to those reported from other countries.

In spite of the fact that unemployment and alcohol consumption are well-accepted suicide risk factors $[6,7,24,60]$, these two indices do not show a strong positive correlation with suicide rate in Hungary between 1992 and 2010. However, a significant positive correlation has been found between tobacco consumption and national suicide rate between 1985 and 2008 [8], which may reflect that, as demonstrated also by our studies in Hungary, patients with mood disorders smoke much more frequently than members of the general population [61] and smoking is a suicide risk factor [6,62]. Moreover, smokers are significantly more impulsive than nonsmokers $[63,64]$, and it is well demonstrated that impulsive-aggressive personality features are powerful predictors of suicidal behavior $[65,66]$.

Looking at the problem of suicide from the side of a given individual, there is no doubt that suicidal behavior is the result of the complex interplay between macro-social and personal suicide risk factors, the most powerful of them is current major depression [3-5]. In agreement with international findings, several studies demonstrated the important role of depression in suicidal behavior in Hungary, as we will discuss below. This is particularly important from a practical point of view, as depression is one of most easily amendable suicide risk factor. 


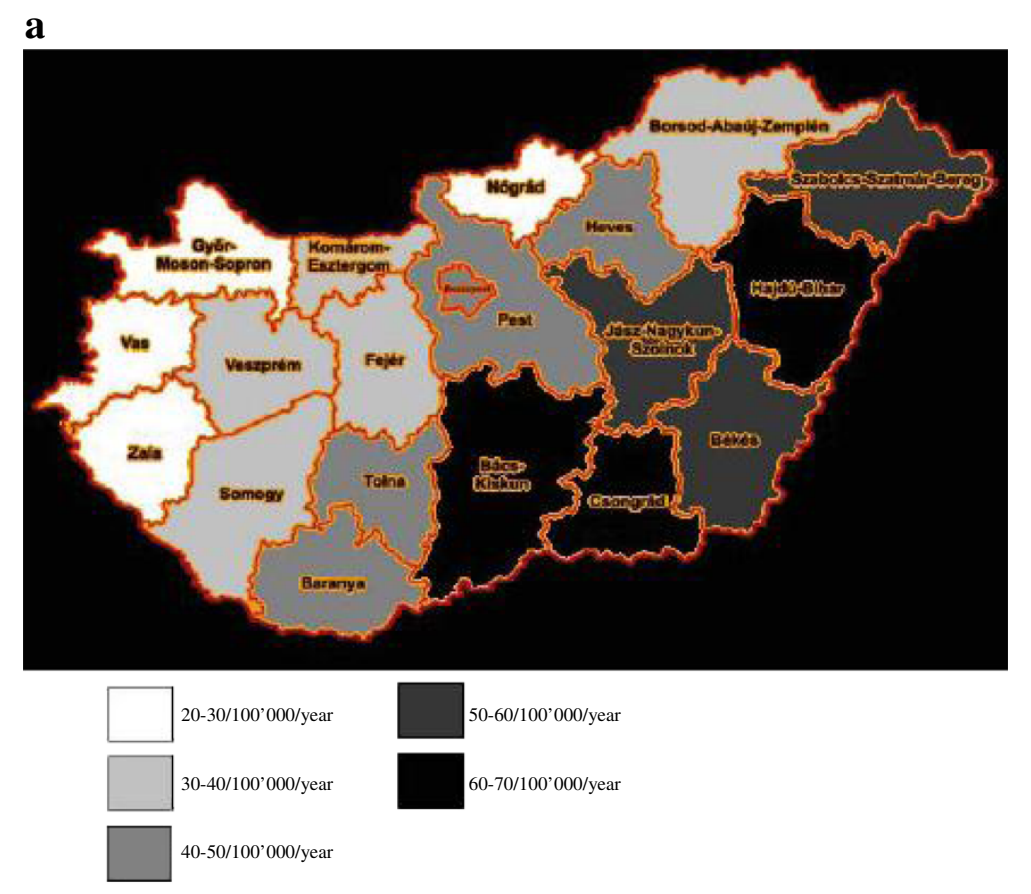

b
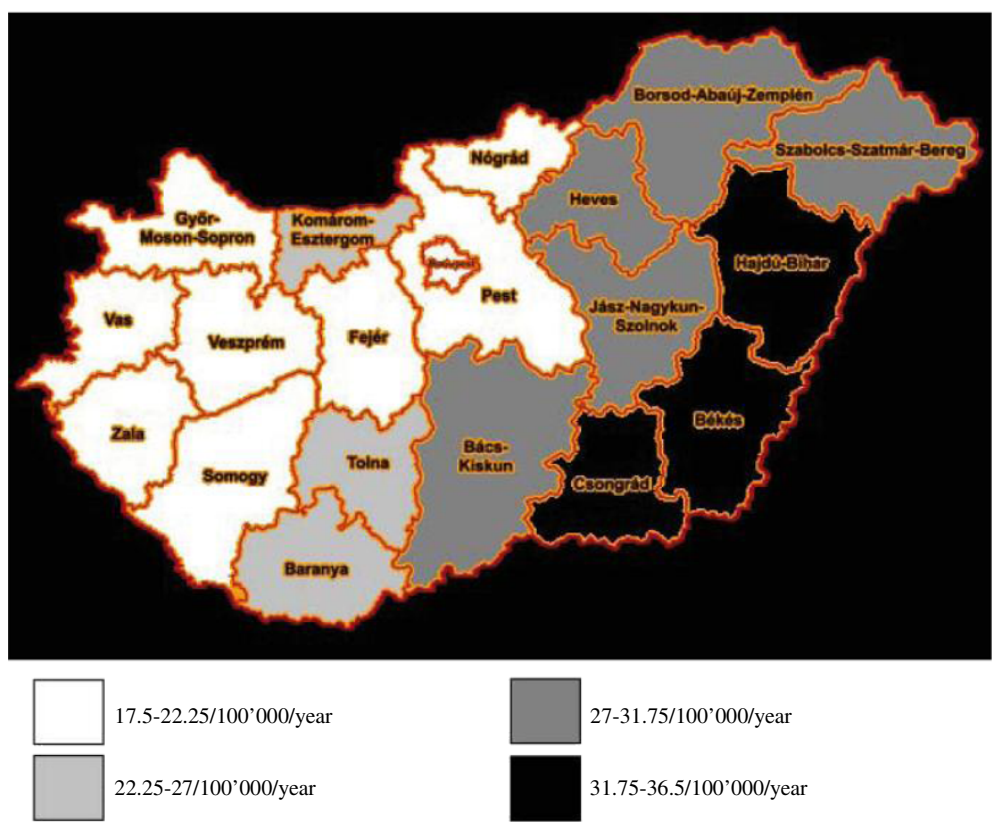

Source: Hungarian Central Statistical Office, Budapest, Hungary.

Figure 2 Suicide rates in Hungarian counties in the year (a) 1980 and (b) 2010.

Investigating the regional distribution of recognized and treated depressions and suicide rates in 20 regions of Hungary in 1985, 1986, and 1987, the suicide rate showed a significant negative correlation with the rate of treated depressions in each of the 3 years: the higher was the rate of treated depressions and the lower was the suicide rate in the given region. It is also important to note that no such relationship was found regarding treated schizophrenic cases [42].

In a psychological autopsy study conducted more than 25 years ago in Budapest, we have found that $63 \%$ of 200 consecutive suicide victims had current depressive 
Table 6 Suicide rates $(n / 100,000 / y e a r)$ in different kinds of Hungarian settlements in 1970, 1980, and 2010

\begin{tabular}{cllll}
\hline Type of settlement & Gender & $\mathbf{1 9 7 0}$ & $\mathbf{1 9 8 0}$ & $\mathbf{2 0 1 0}$ \\
\hline Capital city (Budapest) & Male & 41.71 & 49.55 & 31.91 \\
& Female & $\mathbf{2 9 . 1 2}$ & 42.16 & 11.61 \\
& Total & 35.08 & 45.63 & 20.89 \\
Towns with county's rights & Male & 43.19 & 53.74 & 33.91 \\
(a.k.a. urban counties) & Female & 23.00 & 29.34 & 10.65 \\
& Total & 32.79 & 41.07 & 21.44 \\
Towns & Male & 50.01 & 54.13 & 41.21 \\
& Female & 21.99 & 23.04 & 10.44 \\
& Total & 35.71 & 38.16 & 25.18 \\
& Male & 54.88 & 77.57 & 48.11 \\
& Female & 15.19 & 21.23 & 9.24 \\
& Total & 34.52 & 48.85 & 28.26 \\
\hline
\end{tabular}

Source: Hungarian Central Statistical Office, Budapest, Hungary.

disorders (almost half of them had bipolar depression), 9\% schizophrenia, and 8\% alcoholism [14,67]. More than half of the depressed suicide victims had medical contact during their last depressive episode, but less than $20 \%$ of them received antidepressants and/or mood stabilizers [14]. In a most recent case, control psychological autopsy study in 194 suicide victims and 194 controls in Budapest [6] we also found that $60 \%$ of victims (and $11 \%$ of controls) had current affective disorder, $26 \%$ of victims (and 38\% of controls) had medical contact and $18 \%$ of suicides (and $8 \%$ of controls) took antidepressants in the last 4 weeks before the suicide or before the interview. This study also identified a number of societal factors that may be important determinants of the suicide risk in individuals. It has been found that lifetime history of psychiatric illness, such as separated/divorced/widowed marital status, lower educational level, unemployment, or long-term sick/disabled status, adverse life events within the previous 3 months, alcoholism, and current cigarette smoking, was significantly more common among suicide victims, while being responsible for a child less than 18 years of age and practicing a religion

Table 7 The proportions (\%) of suicide cases by seasons in the Hungarian total population

\begin{tabular}{ccccc}
\hline Year & Spring & Summer & Autumn & Winter \\
\hline 1980 & $28.6 \%$ & $28.8 \%$ & $23.6 \%$ & $19.0 \%$ \\
1985 & $27.1 \%$ & $30.0 \%$ & $24.0 \%$ & $18.9 \%$ \\
1990 & $28.6 \%$ & $26.1 \%$ & $22.3 \%$ & $22.9 \%$ \\
1995 & $28.1 \%$ & $29.0 \%$ & $21.6 \%$ & $21.3 \%$ \\
2000 & $27.2 \%$ & $29.5 \%$ & $22.7 \%$ & $20.6 \%$ \\
2005 & $28.7 \%$ & $27.4 \%$ & $24.2 \%$ & $19.7 \%$ \\
2010 & $27.8 \%$ & $28.3 \%$ & $25.4 \%$ & $18.5 \%$ \\
\hline
\end{tabular}

Table 8 The proportions (\%) of suicide cases by seasons in Hungarian males

\begin{tabular}{lcccc}
\hline Year & Spring & Summer & Autumn & Winter \\
\hline 1980 & $29.0 \%$ & $29.3 \%$ & $23.2 \%$ & $18.5 \%$ \\
1985 & $27.0 \%$ & $30.2 \%$ & $24.2 \%$ & $18.6 \%$ \\
1990 & $28.1 \%$ & $26.6 \%$ & $22.0 \%$ & $23.3 \%$ \\
1995 & $28.0 \%$ & $29.1 \%$ & $21.6 \%$ & $21.3 \%$ \\
2000 & $26.9 \%$ & $30.1 \%$ & $22.0 \%$ & $21.0 \%$ \\
2005 & $28.9 \%$ & $27.3 \%$ & $23.6 \%$ & $20.2 \%$ \\
2010 & $26.7 \%$ & $28.6 \%$ & $25.2 \%$ & $19.4 \%$ \\
\hline
\end{tabular}

was significantly less frequent among the victims than among the controls [6].

Two independent studies on nonviolent suicide attempters (drug overdose or poisoning) in Budapest showed that $69 \%-87 \%$ of the attempters had a current major depressive episode (in many cases with comorbid anxiety and/or substance-use disorders), and unemployment, living alone, and economically inactive status were overrepresented among them $[30,68]$. The strong relationship between suicide attempts and agitated/mixed depression has been also found both in population-based epidemiological [15] and clinical samples [69].

While the suicide rate of Hungary showed a steady (46\%) decline between 1983 and 2006, most of the 'postcommunist' countries (e.g., the Baltic States) exhibited decrease in their suicide mortality only from the mid 1990s, several years after the big political/economic changes started around 1990 (the suicide rate of some other 'post-communist' countries, e.g., Poland and Romania, has reached its zenith even later (in 2005 and 2000, respectively)) [2]. On the other hand, however, the greatest decline in national suicide rate on the world (more than 65\%) between the mid 1980s and 2010 were detected in Denmark, that is not a typical 'post-communist' country [2]. This shows that political/ economic change is probably not the main factor behind this favorable trend. At the same time, between 1983 and 2006, the prescription of antidepressants increased by

Table 9 The proportions (\%) of suicide cases by seasons in Hungarian females

\begin{tabular}{lcccc}
\hline Year & Spring & Summer & Autumn & Winter \\
\hline 1980 & $27.7 \%$ & $27.6 \%$ & $24.8 \%$ & $19.9 \%$ \\
1985 & $27.2 \%$ & $29.3 \%$ & $23.6 \%$ & $19.9 \%$ \\
1990 & $30.2 \%$ & $24.9 \%$ & $23.0 \%$ & $21.9 \%$ \\
1995 & $28.5 \%$ & $28.7 \%$ & $21.4 \%$ & $21.3 \%$ \\
2000 & $28.4 \%$ & $27.5 \%$ & $24.7 \%$ & $19.4 \%$ \\
2005 & $28.0 \%$ & $27.8 \%$ & $26.5 \%$ & $17.7 \%$ \\
2010 & $31.8 \%$ & $26.9 \%$ & $26.0 \%$ & $15.3 \%$ \\
\hline
\end{tabular}

Source: Hungarian Central Statistical Office, Budapest, Hungary. 
tenfold. The negative correlation between antidepressant prescription and national suicide rate in Hungary between 1985 and 2011 is well demonstrated in several previously published papers showing that better recognition and more widespread treatment of depressive disorders, as reflected in the increasing antidepressant utilization, seems to be one of the main contributing factors in the markedly declined suicide rate of Hungary in the last 3 decades $[8,21,23,29,34,70]$. Similarly, a statistically significant correlation between increasing antidepressant utilization and decreasing national suicide rates have been reported recently from several countries [35,71], including Sweden, Denmark, Finland, Norway [3,72,73], the USA [74], Japan [75] and, as mentioned above, Hungary $[8,21,23,29,34,70]$. Although ecological association does not mean causality, considering that

1) there is a strong relationship between untreated major depression and suicide [5,76,77];

2) the appropriate acute and long-term treatment of patients with major depressive and bipolar disorders markedly reduces the suicide mortality even in this high-risk patient-population [5,76,77] and initially suicidal depressives become nonsuicidal with antidepressant treatment $[5,78]$; and

3) the annual prevalence of major depressive episode in the population is around $6 \%-8 \%[18,79]$.

It is logical to assume that more widespread treatment of depression is one of the main causes of declining suicide rates in countries where antidepressant utilization recently increased markedly. On the other hand, however, as national suicide rates are affected by many known (unemployment, divorce rate, alcohol consumption, living standard, etc.) and unknown factors [80,81], the isolation of the result of better treatment of depression in declining suicide rates is not easy.

The increase in antidepressant utilization, as reflected in antidepressant prescriptions, is only a proxy marker of greater access of patients to appropriate care, and higher population density of doctors in general $[82,83]$ and psychiatrists and psychotherapists in particular $[21,22,83]$ are negatively associated with national and regional suicide rates. It is likely that many patients receiving antidepressants also receive a prescription of lithium and other mood stabilizers as well as they receive more frequently supportive or specific psychotherapy for depression. Between 1982 and 2000, the number of psychiatrists in Hungary increased from 550 to 850 , as well as the number of outpatient psychiatric departments (from 95 to 139), and the number of S.O.S. telephone services (from 5 to 28) [70]. It should be also noted that between 1990 and 2010, the number of telephones (the best mean for rapid communication even in the case of suicidal crisis) increased by fivefold in Hungary, and recently, the number of ordinary and mobile phones is over 11 million while the population of the country is 10 million. Although it is not possible to measure, it is very likely that the new democratic political system since 1990 (including freedom of religion and several newly founded civil organizations) plays also important role in this favorable process. Therefore, the decrease of suicide rates could reflect a general improvement in mental health care rather than being caused by increasing antidepressant sales alone. The robust increase of antidepressant prescription in Hungary remains the only consistent correlate of declining national suicide rate of Hungary in the last 25-30 years $[8,21,23,34,70]$, indicating that better recognition and treatment of depression is one, but not the only, important contributor to this favorable change. On the other hand, however, recently, we have suggested that increasing unemployment rate after 2005 might be one of the contributing factors that accounted for the disappearance of the strong decreasing trend from the Hungarian suicide rate that stabilized around 24/100,000 between 2006 and 2011 [25]. The exact causes, the role of possible contributory factors as well as the relationship between them remain to be elucidated, yet it seems increasingly obvious that patterns and trends in suicide rates in Hungary are determined by a delicate interplay between various genetic, psychiatric, cultural, economic, political, social, and treatment-related factors specific for Hungary.

In spite of the great decline in the suicide rates of Hungary in recent decades most likely resulting from advancements in Hungarian healthcare well indicating the possibilities for suicide prevention, there is, unfortunately, no centrally directed, government-organized suicide prevention program in Hungary. However, in the last 20-25 years the importance of psychiatric disorders (particularly depression) in suicide and suicide prevention receives more and more attention in the training of medical students, residents, psychiatrists, and general practitioners. These regular trainings are organized by the four medical universities (Budapest, Pécs, Szeged, Debrecen), the Hungarian Psychiatric Association, the Association of Hungarian Neuropsychopharmacologists, and also by pharmaceutical companies. In spite of the fact that the decline of national suicide mortality in Hungary in the last 25 years (46\%) is among the greatest decreases in the world, the suicide rate of Hungary is still very high (in 2011, 24.3/100,000), so much remains to be done.

In agreement with the findings of the Swedish Gotland Study [84], our community-intervention suicide preventive project in the Kiskunhalas region of Hungary $(68,000$ inhabitants) between 2000 and 2005 showed that education of doctors, other healthcare professionals, and gatekeepers, as well as the public, is an effective method of reducing 
suicide mortality [85]. The Hungarian Depression Recognition and Suicide Prevention Program in Szolnok between 2004 and 2006 (as a part of the European Alliance Against Depression program) directed by Maria Kopp also supported the key role of general practitioners and other gatekeepers (psychiatrists, psychologists, telephone help service providers, pharmacists, teachers, pastors, police officers, family nurses, geriatric care providers, etc.) in suicide prevention [86].

Screening and also medical care for those at increased risk of suicide should be extended from psychiatric practices to all specialities of healthcare, especially to primary care, and primary care providers should not only be qualified to screen for depression and suicide risk, but should also provide subsequent care for previous suicide attempters since previous attempts are among the major risk factors for suicide. Also, in primary care practices, family suicide events, another important risk factor, should also be screened for [87]. General practitioners are in the best position to detect if multiple important risk factors of the suicide constellation are present in case of their patients and could provide referral to mental health care or counselling services.

As psychosocial and community factors also play an important role in suicidal behavior, it is not only health care workers who are responsible for its prevention. Improving well-being and quality of life of people in general (including decreasing unemployment and providing more support for health and social services), restricting lethal suicide methods (e.g., reducing domestic and car exhaust gas toxicity and introducing stricter laws on gun control), and initiating more restricitve alcohol and smoking policies, which may also reduce suicide mortality $[4,9,88,89]$, exceed the limits and jurisdiction of health and social care and are rather the leaders' competence and responsibility at any level of the society. Individual programs developed and implemented in each level of the society, however, need to be coordinated by a unified, government-level central suicide prevention plan. A central prevention plan should appoint possible targets of prediction, prevention, and intervention, at multiple levels and building on multiple groups within the society. The suicide prevention plan should include guidelines for data collection concerning suicide and its risk factors; outline of necessary changes in medical training; training for workers in the social field; and also training for church associated persons as well as teachers and policemen; enhancing scientific research in related fields, tackling ethical, moral, and legal issues related to suicide; and changing legislation if necessary, designing and launching public campaigns, planning enlightenment campaigns, and creating possibilities for interventions in schools. Coordinators at all levels should also be appointed. However, for such a plan to be realized, first awareness concerning the burning issue of suicide in Hungary should be raised not only for the population but also for politicians, legislators, and health/social care decision makers.

\section{Conclusion}

In our review, we tried to collect the current knowledge and data on the main topics of the Hungarian suicide scene and also on the pilot projects which were conducted in order to better prevention of suicide cases. Our primary aim with this review was to draw attention to the severity of suicide scene in Hungary, a problem which has however shown an improving trend in the last decades but still poses a serious burden to the society.

We also hope that these raw data, and our inferences and proposals based on them, will be taken into account by the political and academic decision makers when they will consider the necessity of the launching of a nationwide prevention program and the concommitant scientific research on the background mechanisms as well.

We are, of course, unable to prevent all suicides. Nevertheless, the already existing theoretical knowledge and the available treatment and preventive strategies are sufficient to prevent many, probably the majority, of them.

\section{Competing interests}

The authors declare that they have no competing interests.

\section{Authors' contributions}

ZR and PD conceived the main idea of this review. BK gathered raw data. XG conducted literature search. All authors participated in preparing the manuscript. All authors read and approved the final manuscript.

\section{Acknowledgement}

Peter Dome and Xenia Gonda are recipients of the Bolyai János Postdoctoral Fellowship of the Hungarian Academy of Sciences.

\section{Author details}

'Department of Clinical and Theoretical Mental Health, Faculty of Medicine, Semmelweis University, Budapest, Hungary. ${ }^{2}$ Department of Psychiatry and Psychotherapy, Faculty of Medicine, Semmelweis University, Budapest, Hungary. ${ }^{3}$ Demographic Research Institute of the Hungarian Central Statistical Office, Budapest, Hungary.

\section{Received: 11 April 2013 Accepted: 17 June 2013}

Published: 26 June 2013

\section{References}

1. Levi F, La Vecchia C, Lucchini F, Negri E, Saxena S, Maulik PK, Saraceno B: Trends in mortality from suicide, 1965-99. Acta Psychiat Scand 2003, 108:341-349.

2. World Health Organization: WHO mortality database. http://apps.who.int/ healthinfo/statistics/mortality/whodpms/, http://www.who.int/ mental_health/prevention/suicide/country_reports/en/index.html.

3. Isacsson G: Suicide prevention-a medical breakthrough? Acta Psychiatr Scand 2000, 102:113-117.

4. Rihmer Z, Belső N, Kiss K: Strategies for suicide prevention. Curr Opin Psychiatry 2002, 15:83-87.

5. Rihmer Z: Suicide risk in mood disorders. Curr Opin Psychiatry 2007 20:17-22.

6. Almasi K, Belso N, Kapur N, Webb R, Cooper J, Hadley S, Kerfoot M, Dunn G, Sotonyi P, Rihmer Z, Appleby L: Risk factors for suicide in Hungary: a case-control study. BMC Psychiatry 2009, 9:45.

7. Sher L: Alcoholism and suicidal behavior: a clinical overview. Acta Psychiat Scand 2006, 113:13-22 
8. Döme P, Kapitány B, Ignits G, Porkoláb L, Rihmer Z: Tobacco consumption and antidepressant use are associated with the rate of completed suicide in Hungary: an ecological study. J Psychiatr Res 2011, 45:488-494.

9. Wasserman D: Suicide: An Unnecessary Death. London: Martin Dunitz; 2000.

10. Rihmer Z, Akiskal H: Do antidepressants $t(h)$ reat(en) depressives? Toward a clinically judicious formulation of the antidepressant-suicidality FDA advisory in light of declining national suicide statistics from many countries. J Affect Disord 2006, 94:3-13.

11. Lester D: Explaining regional differences in suicide rates. Soc Sci Med 1995, 40:719-721.

12. Voracek M, Loibl LM, Kandrychyn S: Testing the Finno-Ugrian suicide hypothesis: replication and refinement with regional suicide data from Eastern Europe. Percept Mot Skills 2007, 104:985-994.

13. Voracek $M$, Vintilă $M$, Muranyi $D$ : A further test of the Finno-Ugrian suicide hypothesis: correspondence of county suicide rates in Romania and population proportion of ethnic Hungarians. Percept Mot Skills 2007, 105:1209-1222.

14. Rihmer Z, Barsi J, Arató M, Demeter E: Suicide in subtypes of primary major depression. J Affect Disord 1990, 18:221-225.

15. Szádóczky E, Vitrai J, Rihmer Z, Füredi J: Suicide attempts in the Hungarian adult population. Their relation with DIS/DSM-III-R affective and anxiety disorders. Eur Psychiatry 2000, 15:343-347.

16. Rihmer Z: Prediction and prevention of suicide in bipolar disorders. Clin Neuropsychiatry 2005, 2:48-54.

17. Pini S, de Queiroz V, Pagnin D, Pezawas L, Angst J, Cassano GB, Wittchen $\mathrm{HU}$ : Prevalence and burden of bipolar disorders in European countries. Eur Neuropsychopharmacol 2005, 15:425-434.

18. Szádóczky E, Papp Z, Vitrai J, Ríhmer Z, Füredi J: The prevalence of major depressive and bipolar disorders in Hungary: results from a national epidemiologic survey. J Affect Disord 1998, 50:153-162

19. Hasin DS, Goodwin RD, Stinson FS, Grant BF: Epidemiology of major depressive disorder: results from the National Epidemiologic Survey on alcoholism and related conditions. Arch Gen Psychiatry 2005, 62:1097-1106.

20. Van de Velde S, Bracke P, Levecque K: Gender differences in depression in 23 European countries: cross-national variation in the gender gap in depression. Soc Sci Med 2010, 71:305-313.

21. Rihmer Z: Decreasing national suicide rates-fact or fiction? World J Biol Psychiatry 2004, 5:55-56.

22. Kapusta ND, Niederkrotenthaler T, Etzersdorfer E, Voracek M, Dervic K, Jandl-Jager E, Sonneck G: Influence of psychotherapist density and antidepressant sales on suicide rates. Acta Psychiatr Scand 2009, 119:236-242.

23. Sebestyen B, Rihmer Z, Balint L, Szokontor N, Gonda X, Gyarmati B, Bodecs $T$, Sandor J: Gender differences in antidepressant use-related seasonality change in suicide mortality in Hungary, 1998-2006. World J Biol Psychiatry 2010, 11:579-585.

24. Stuckler D, Basu S, Suhracke M, Coutts A, McKee M: Effects of the 2008 recession on health: a first look at European data. Lancet 2011, 378:124-125.

25. Rihmer Z, Kapitany B, Gonda X, Dome P: Suicide, recession, and unemployment. Lancet 2013, 381:722-723.

26. Bálint L: Öngyilkosságok Magyarországon - néhány területi jellegzetesség. Területi Statisztika 2008, 11:573-591.

27. Hawton K, van Heeringen K: Suicide. Lancet 2009, 373:1372-1381

28. Brådvik L: Violent and nonviolent methods of suicide: different patterns may be found in men and women with severe depression. Arch Suicide Res 2007, 11:255-264.

29. Berecz R, Cáceres M, Szlivka A, Dorado P, Bartók E, Peñas-LLedó E, LLerena A, Degrell I: Reduced completed suicide rate in Hungary from 1990 to 2001: relation to suicide methods. J Affect Disord 2005, 88:235-238.

30. Rihmer A, Rozsa S, Rihmer Z, Gonda X, Akiskal KK, Akiskal HS: Affective temperaments, as measured by TEMPS-A, among nonviolent suicide attempters. J Affect Disord 2009, 116:18-22.

31. Balázs J, Bitter I, Lecrubier Y, Csiszér N, Ostorharics G: Prevalence of subthreshold forms of psychiatric disorders in persons making suicide attempts in Hungary. Eur Psychiatry 2000, 15:354-361.

32. Fekete S, Voros V, Osvath P: Gender differences in suicide attempters in Hungary: retrospective epidemiological study. Croat Med J 2005 46:288-293

33. Bitter I, Kurimay T: State of psychiatry in Hungary. Int Rev Psychiatry 2012, 24:307-313.
34. Kalmar S, Szanto K, Rihmer Z, Mazumdar S, Harrison K, Mann JJ: Antidepressant prescription and suicide rates: effect of age and gender. Suicide Life Threat Behav 2008, 38:363-374

35. Ludwig J, Marcotte DE, Norberg K: Anti-depressants and suicide. J Health Econ 2009, 28:659-676

36. Corcoran P, Nagar A: Suicide and marital status in Northern Ireland. Soc Psychiatry Psychiatr Epidemiol 2010, 45:795-800

37. Lester D, Rihmer Z: The regional variation of divorce in Hungary. J Divorce Remarriage 1997, 26:83-85.

38. Smith JC, Mercy JA, Conn JM: Marital status and the risk of suicide. Am J Public Health 1988, 78:78-80.

39. Yip PS, Thorburn J: Marital status and the risk of suicide: experience from England and Wales, 1982-1996. Psychol Rep 2004, 94:401-407.

40. Masocco M, Pompili M, Vanacore N, Innamorati M, Lester D, Girardi P, Tatarelli R, Vichi M: Completed suicide and marital status according to the Italian region of origin. Psychiatr Q 2010, 81:57-71.

41. Neeleman J: Regional suicide rates in the Netherlands: does religion still play a role? Int J Epidemiol 1998, 27:466-472.

42. Rihmer Z, Barsi J, Veg K, Katona CL: Suicide rates in Hungary correlate negatively with reported rates of depression. J Affect Disord 1990, 20:87-91.

43. Zonda $T$, Veres $E$, Juhász J: Az öngyilkosság, mint a társadalmi anomia területi konzekvenciái. A Falu 2010, 25:57-69.

44. Buda B: Az öngyilkosság. Orvosi és társadalomtudományi tanulmányok. 2nd edition. Budapest: Animula Kiadó; 2001.

45. Kopp M, Skrabski Á, Szedmák S: Socio-economic factors, severity of depressive symptomatology and sickness absence rate in the Hungarian population. J Psychosomatic Res 1995, 39:1019-1029.

46. Szèkely A, Purebl G: Összefogás a depresszió ellen. In A depresszió terület megoszlása Magyarországon 1995-ben és 2002-ben. Edited by Csépe A. Budapest: Semmelweis Kiadó: Kézikönyv a segítő foglalkozásúak számára; 2007:28-46.

47. Moksony F: Születési régió és öngyilkosság: Létezik-e az önpusztítás területi szubkultúrája? Demográfia 2003, 46:203-225.

48. Kapusta ND, Zorman A, Etzersdorfer E, Ponocny-Seliger E, Jandl-Jager E, Sonneck G: Rural-urban differences in Austrian suicides. Soc Psychiatry Psychiatr Epidemiol 2008, 43:311-318.

49. Christodoulou C, Douzenis A, Papadopoulos FC, Papadopoulou A, Bouras G, Gournellis R, Lykouras L: Suicide and seasonality. Acta Psychiatr Scand 2012, 125:127-146.

50. Reutfors J, Osby U, Ekbom A, Nordström P, Jokinen J, Papadopoulos FC: Seasonality of suicide in Sweden: relationship with psychiatric disorder. J Affect Disord 2009, 119:59-65.

51. Postolache T, Mortensen PB, Tonelli LH, Jiao X, Frangakis C, Soriano JJ, Qin P: Seasonal spring peaks of suicide in victims with and without prior history of hospitalization for mood disorders. J Affect Disord 2010, 121:88-93.

52. Voracek M, Yip PS, Fisher ML, Zonda T: Seasonality of suicide in Eastern Europe: a rejoinder to Lester and Moksony. Percept Mot Skills 2004, 99:17-18.

53. Mergl R, Havers I, Althaus D, Rihmer Z, Schmidtke A, Lehfeld H, Niklewski G, Hegerl U: Seasonality of suicide attempts: association with gender. Eur Arch Psychiatry Clin Neurosci 2010, 260:393-400.

54. Rihmer Z, Rutz W, Pihlgren H, Pestality P: Decreasing tendency of seasonality in suicide may indicate lowering rate of depressive suicides in the population. Psychiatry Res 1998, 81:233-240.

55. Lester D, Moksony F: The seasonality of suicide in Hungary in the 1930 s. Percept Mot Skills 2007, 105:714.

56. Lester D, Moksony F: Seasonality of suicide in eastern Europe: a comment on "Evidence for lack of change in seasonality of \& suicide from Timis County, Romania". Percept Mot Skills 2003, 96:421-422.

57. Zonda T, Bozsonyi $K$, Veres E: Seasonal fluctuation of suicide in Hungary between 1970-2000. Arch Suicide Res 2005, 9:77-85

58. Ohtsu T, Kokaze A, Osaki Y, Kaneita Y, Shirasawa T, Ito T, Sekii H, Kawamoto T, Hashimoto M, Ohida T: Blue Monday phenomenon among men: suicide deaths in Japan. Acta Med Okayama 2009, 63:231-236

59. Zonda T, Bozsonyi K, Veres $E$, Lester D, Frank M: The impact of holidays on suicide in Hungary. Omega (Westport) 2008-2009, 58:62-153.

60. Razvodovsky YE: Alcohol consumption and suicide in Belarus, 1980-2005. Suicidology Online 2011, 2:1-7. 
61. Döme P, Rihmer Z, Gonda X, Pestality P, Kovács G, Teleki Z, Mandl P: Cigarette smoking and psychiatric disorders in Hungary. Int J Psychiatry Clin Practice 2005, 9:145-148.

62. Rihmer Z, Döme P, Gonda X, Kiss HG, Kovács D, Seregi K, Teleki Z: Cigarette smoking and suicide attempts in psychiatric outpatients in Hungary. Neuropsychopharmacol Hung 2007, 9:63-67.

63. Mitchell SH: Measuring impulsivity and modeling its association with cigarette smoking. Behav Cogn Neurosci Rev 2004, 3:261-275.

64. Ostacher MJ, Lebeau RT, Perlis RH, Nierenberg AA, Lund HG, Moshier SJ, Sachs GS, Simon NM: Cigarette smoking is associated with suicidality in bipolar disorder. Bipolar Disord 2009, 11:766-771.

65. Mann JJ, Waternaux C, Haas GL, Malone KM: Toward a clinical model of suicidal behavior in psychiatric patients. Am J Psychiatry 1999, 156:181-189.

66. Swann AC, Dougherty DM, Pazzaglia PJ, Pham M, Steinberg JL, Moeller FG: Increased impulsivity associated with severity of suicide attempt history in patients with bipolar disorder. Am J Psychiatry 2005, 162:1680-1687.

67. Arató M, Demeter E, Rihmer Z, Somogyi E: Retrospective psychiatric assessment of 200 suicides in Budapest. Acta Psychiatr Scand 1988, 77:454-456.

68. Balázs J, Lecrubier Y, Csiszér N, Koszták J, Bitter I: Prevalence and comorbidity of affective disorders in persons making suicide attempts in Hungary: importance of the first depressive episodes and of bipolar II diagnoses. J Affect Disord 2003, 76:113-119.

69. Balázs J, Benazzi F, Rihmer Z, Rihmer A, Akiskal KK, Akiskal HS: The close link between suicide attempts and mixed (bipolar) depression: implications for suicide prevention. J Affect Disord 2006, 91:133-138.

70. Rihmer Z, Belső N, Kalmár S: Antidepressants and suicide prevention in Hungary. Acta Psychiat Scand 2001, 103:238-239.

71. Ludwig J, Marcotte DE: Anti-depressants, suicide, and drug regulation. J Policy Anal Manage 2005, 24:249-272.

72. Søndergård L, Kvist K, Lopez AG, Andersen PK, Kessing LV: Temporal changes in suicide rates for persons treated and not treated with antidepressants in Denmark during 1995-1999. Acta Psychiatr Scand 2006, 114:168-176.

73. Bramness JG, Walby FA, Tverdal A: The sales of antidepressants and suicide rates in Norway and its counties 1980-2004. J Affect Disord 2007, 102:1-9.

74. Grunebaum MF, Ellis SP, Li S, Oquendo MA, Mann JJ: Antidepressants and suicide risk in the United States, 1985-1999. J Clin Psychiatry 2004 65:1456-1462.

75. Nakagawa A, Grunebaum MF, Ellis SP, Oquendo MA, Kashima H, Gibbons RD, Mann JJ: Association of suicide and antidepressant prescription rates in Japan, 1999-2003. J Clin Psychiatry 2007, 68:908-916.

76. Baldessarini RJ, Tondo L, Davis P, Pompili M, Goodwin FK, Hennen J: Decreased risk of suicides and attempts during long-term lithium treatment: a meta-analytic review. Bipolar Disord 2006, 8:625-639.

77. Möller HJ: Evidence for beneficial effects of antidepressants on suicidality in depressive patients: a systematic review. Eur Arch Psychiatry Clin Neurosci 2006, 256:329-343.

78. Tondo L, Lepri B, Baldessarini RJ: Suicidal status during antidepressant treatment in 789 Sardinian patients with major affective disorder. Acta Psychiatr Scand 2008, 118:106-115.

79. Rihmer Z, Angst J: Mood disorders - epidemiology. In Kaplan and Sadock's Comprehensive Textbook of Psychiatry. 8th edition. Edited by Sadock BJ, Sadock VA. Philadelphia: Lippincott Williams and Wilkins; 2005:1575-1581.

80. Gunnell D, Middleton N, Whitley E, Dorling D, Frankel S: Why are suicide rates rising in young men but falling in the elderly?- a time-series analysis of trends in England and Wales 1950-1998. Soc Sci Med 2003 57:595-611.

81. Preti A: Seasonal variation and meteotropism in suicide: clinical relevance of findings and implications for research. Acta Neuropsychiatr 2002, 14:17-28.

82. Rihmer Z, Rutz W, Barsi J: Suicide rate, prevalence of diagnosed depression and prevalence of working physicians in Hungary. Acta Psychiatr Scand 1993, 88:391-394.

83. Tondo L, Albert MJ, Baldessarini RJ: Suicide rates in relation to health care access in the United States: an ecological study. J Clin Psychiatry 2006, 67:517-523.

84. Rutz W, von Knorring L, Walinder J: Frequency of suicide on Gotland after systematic postgraduate education of general practitioners. Acta Psychiatr Scand 1989, 80:151-154.
85. Szanto K, Kalmar S, Hendin H, Rihmer Z, Mann JJ: A suicide prevention program in a region with a very high suicide rate. Arch Gen Psychiatry 2007, 64:914-920.

86. Torzsa P, Székely A, Bagi M, Purebl G, Kopp M: Az “Európai Szövetség a Depresszió Ellen" magyarországi programjának bemutatása. Magyar Családorvosok Lapja 2009, 1:12-17.

87. Torzsa P, Rihmer Z, Gonda X, Szokontor N, Sebestyén B, Kalabay L: Family History of suicide: a clinical marker for major depression in primary care practice? J Affect Disord 2009, 117:202-204.

88. Värnik A, Wasserman D, Dankowicz M, Eklund G: Marked decrease in suicide among men and women in the former USSR during perestroika. Acta Psychiatr Scand Supp/ 1998, 394:13-19.

89. Dome P, Lazary J, Kalapos MP, Rihmer Z: Smoking, nicotine and neuropsychiatric disorders. Neurosci Biobehav Rev 2010, 34:295-342.

doi:10.1186/1744-859X-12-21

Cite this article as: Rihmer et al: Suicide in Hungary-epidemiological and clinical perspectives. Annals of General Psychiatry 2013 12:21.

\section{Submit your next manuscript to BioMed Central and take full advantage of:}

- Convenient online submission

- Thorough peer review

- No space constraints or color figure charges

- Immediate publication on acceptance

- Inclusion in PubMed, CAS, Scopus and Google Scholar

- Research which is freely available for redistribution 